\section{The Management and Funding of US Study Abroad}

\section{Brian WhaLEN}

Brian Whalen is associate dean of Dickenson College and executive director of the college's Office of Clobal Education in Carlisle, Pennsylvania, USA. $\mathrm{He}$ is also president and CEO of the Forum on Education Abroad. Web site: www.forumea.org. E-mail: whalenb@dickinson.edu.

$\mathrm{U}$ S colleges and universities manage and fund study-abroad programs in a tremendous variety of ways. The wide range includes types of programs, policies for awarding academic credit, structuring of study-abroad program fees, systems for funding the study-abroad office, program evaluation methods, and other areas of program management. US colleges and universities frequently partner with overseas universities and program providers.

A recent survey conducted by the Forum on Education Abroad gives some useful data on the diverse management practices in US education abroad (www.forumea.org). Institutional members of the forum include 275 US colleges and universities, international universities, study-abroad-program providers, and independent organizations. This group accounts for approximately 75 percent of the US students studying abroad each year. Over one-third of the members responded to the forum's survey, providing a comprehensive picture of how US study abroad works.

Regarding their international education programs, US colleges and universities have different approaches for developing and overseeing their curricula, which affects the educationabroad practices. The number and types of programs, the program models, the role of faculty, and policies for the awarding of credit vary from institution to institution. Study-abroad business models are based on the many factors influencing institutions' decisions and best practices for funding education abroad. Charging "home-school fees," adding a study-abroad fee, negotiating a discount with a program provider, controlling the number of students allowed to study abroad and for how long include some of the practices that differ from institution to institution.

\section{Diverse Program Types}

Curricular diversity can be seen in the many types of studyabroad programs offered by institutions. Over 85 percent of US colleges and universities report that they offer multiple types of education-abroad programs: with at least one special course developed for US or other international students on the program (93\%); integrated university study, where students take regular university courses (93\%); reciprocal exchange (89\%); and faculty-led, short-term (less than a quarter or semester) programs (86\%). Additionally, over half the institutions offer faculty-led, long-term (one quarter or semester or longer) programs $(55 \%)$, while in a number of cases faculty take students abroad for course work on sojourns rather than formally approved study abroad programs (53\%). The majority of provider-funded study-abroad programs include at least one special course (95\%), followed by integrated university study $(60 \%)$, faculty-led, short-term study $(50 \%)$, reciprocal exchange (30\%), and faculty-led, long-term programs (I0\%).

\section{Study Abroad Funding}

Study-abroad offices and programs are generally funded through the institution's general resources and revenue from study-abroad-program fees. Three-quarters of US study-abroad offices are funded by general funds, while half the institutions fund the office through the study-abroad fees paid by students, with the average funding level consisting of 60 percent of the office's operation. Most institutions support the programs from the general budget and study-abroad fees, although other reported sources of funding include student fees paid by every student at the institution, restricted endowments, and cost sharing provided by program providers.

US colleges and universities have different approaches for developing and overseeing their curricula, which affects the education-abroad practices.

\section{Institutions and Program Providers}

US colleges and universities often depend on study-abroadprovider organizations (both nonprofit and for-profit), overseas universities, and independent programs to organize these programs; and these partnerships take many forms. Institutions partner with provider organizations half the time $(50 \%)$ when running programs with at least one special course and no onsite participation by the institution's faculty, and 35 percent cooperate with providers when offering nonexchange programs with integrated university study.

Academic quality is the most reported factor that colleges and universities consider when deciding to affiliate with or approve programs. The next most important factors reported include health and safety, quality of program administration and ease of working with program provider, in-country support (e.g., resident directors, cocurricular activities), and program structure (e.g., direct enrollment, hybrid, field study). Notably, despite media reports about program discounts, the cost of study-abroad programs ranks only sixth on the list.

Institutions set the fees for affiliated or approved studyabroad programs in different ways, with the single-most-common practice being that students pay the program provider directly $(35 \%)$. Other approaches are almost as common and 
include students paying the institution for the program fee and the institution then paying the program (31\%); students paying full-home-school tuition but paying for their own room and board (29\%); students paying full-home-school tuition and fees and the institution paying all of the program expenses, including room and board (18\%). In addition, some institutions report that they assess an additional fee that study-abroad students must pay.

\section{Study-abroad offices and programs are generally funded through the institution's general resources and revenue from study-abroad-program fees.}

Institutions report that they commonly negotiate reduced program fees with provider organizations. Forty-four percent of institutions reported that in deciding whether to affiliate with a program they negotiated fee reductions ("always" or "sometimes") for each student sent on the provider's program. Fewer institutions report that they ("always" or "sometimes") negotiate rebates for each student sent $(8 \%)$, with this rebate funding used to support their study-abroad office. A more common approach employed by institutions is to negotiate scholarships for their students, with 38 percent of institutions reporting that they ("always" or "sometimes") take part in this practice. Seventeen percent of institutions report that they ("always" or "sometimes") negotiate scholarships based on student volume.

Also noteworthy, given the recent media coverage in the United States, only 3 percent (two institutions) reported having exclusive agreements with program providers. "Exclusive agreement" here refers to the practice of an institution not affiliating with or not permitting a student to enroll in any other study-abroad program in the same city, country, or region covered by the provider program. Based on the survey, exclusive agreements appear to be an uncommon practice.

Another aspect of the relationship between colleges and universities and study-abroad-provider organizations is institutional representation on the program providers' external advisory boards or committees. Seventy-four percent of provider organizations report that they have an external advisory board or committee or similar group, demonstrating how common this practice is. Provider organizations report that these entities have several responsibilities. Eighty percent of organizations report that they provide guidance on the needs of institutions and 80 percent report that they provide guidance on the needs of students. Fifty-three percent report that such boards give credibility to the program provider's offerings. Almost half of program providers $(47 \%)$ report that these bodies are utilized to evaluate programs, while $33 \%$ of them report that the advisory board actually approves programs.

\section{Financial Aid for Students}

It is not surprising that some portion of study-abroad fees go to institutions' general funds given the amount of financial aid that institutions provide for students who study abroad. About 75 percent of US institutions report that their students who study abroad receive need-based and merit institutional financial aid when they study on the institution's programs, while approximately 60 percent report their students receive this type of aid when they study on programs on an approved list. Most provider organizations also offer scholarship funding to students in a variety of ways, with the most prevalent practice, reported by $\sigma_{3}$ percent of organizations, being that students apply directly to the organization for scholarships.

\section{Standardization or Adherence to Standards}

Some might suggest that the diversity of approaches and practices among US institutions represents a failure of the education-abroad field to agree on a set of standard practices. It would be a mistake, however, to recommend that all institutions and study-abroad organizations adopt the same specific policies and practices. Nevertheless, institutions and provider organizations should agree on a set of principles that guide study-abroad management and funding practices.

While adhering to standards of good practice does not mean adopting the standardization of practices, it does mean practicing transparency and openness, avoiding conflicts of interest, and keeping the student-learning experience foremost in mind. Institutions and organizations that adopt standards of good practice show that they are committed to being clear and consistent about their mission and goals, and employ continuous quality improvement.

\section{US Accreditation: Bridging the International and National Dialogue Gap}

\section{Judith S. Eaton}

Judith S. Eaton is president of the Council for Higher Education Accreditation, a nongovernmental institutional membership organization that provides national coordination of accreditation in the United States. E-mail: eaton@chea.org.

Throughout this decade, international conversations about 1 higher education have been punctuated with significant attention to accreditation and quality assurance. Whether the subject is expanding access to higher education, the need for global competitiveness, or the imperative to create knowledge 